\title{
Erratum to: 'Expression of granzyme B sensitizes ALK+ ALCL tumour cells to apoptosis-inducing drugs'
}

Jodel D. Pearson ${ }^{1}$, Jingxi Zhang ${ }^{1}$, Zuoqiao Wu', Kayla D. Thew ${ }^{1}$, Katelynn J. Rowe', Julinor T. C. Bacani² and Robert J. Ingham ${ }^{1 *}$

Unfortunately, the original version of this article [1] contained an error. A figure was mislabelled. In Figs. 5c and $\mathrm{d}$ the Doxorubicin (Doxo) concentrations should be in $\mu \mathrm{M}$. Here is most recent version of the figure with it correctly labelled.

\begin{abstract}
Author details
'Department of Medical Microbiology and Immunology and Li Ka Shing Institute of Virology, University of Alberta, Katz Group Centre for Pharmacy and Health Research, University of Alberta, Edmonton, Canada. ${ }^{2}$ Department of Laboratory Medicine and Pathology, University of Alberta, Edmonton, Canada.
\end{abstract}

Received: 9 February 2016 Accepted: 9 February 2016 Published: 1 March 2016

\section{Reference}

1. Pearson JD, Zhang J, Wu Z, Thew KD, Rowe KJ, Bacani JTC, Ingham RJ. Expression of granzyme B sensitizes ALK+ ALCL tumour cells to apoptosisinducing drugs. Molecular Cancer. 2014;13:199.

\footnotetext{
*Correspondence: ringham@ualberta.ca

'Department of Medical Microbiology and Immunology and Li Ka Shing Institute of Virology, University of Alberta, Katz Group Centre for Pharmacy and Health Research, University of Alberta, Edmonton, Canada
}

Submit your next manuscript to BioMed Central and we will help you at every step:

- We accept pre-submission inquiries

- Our selector tool helps you to find the most relevant journal

- We provide round the clock customer support

- Convenient online submission

- Thorough peer review

- Inclusion in PubMed and all major indexing services

- Maximum visibility for your research

Submit your manuscript at

www.biomedcentral.com/submit

\section{() Biomed Central}




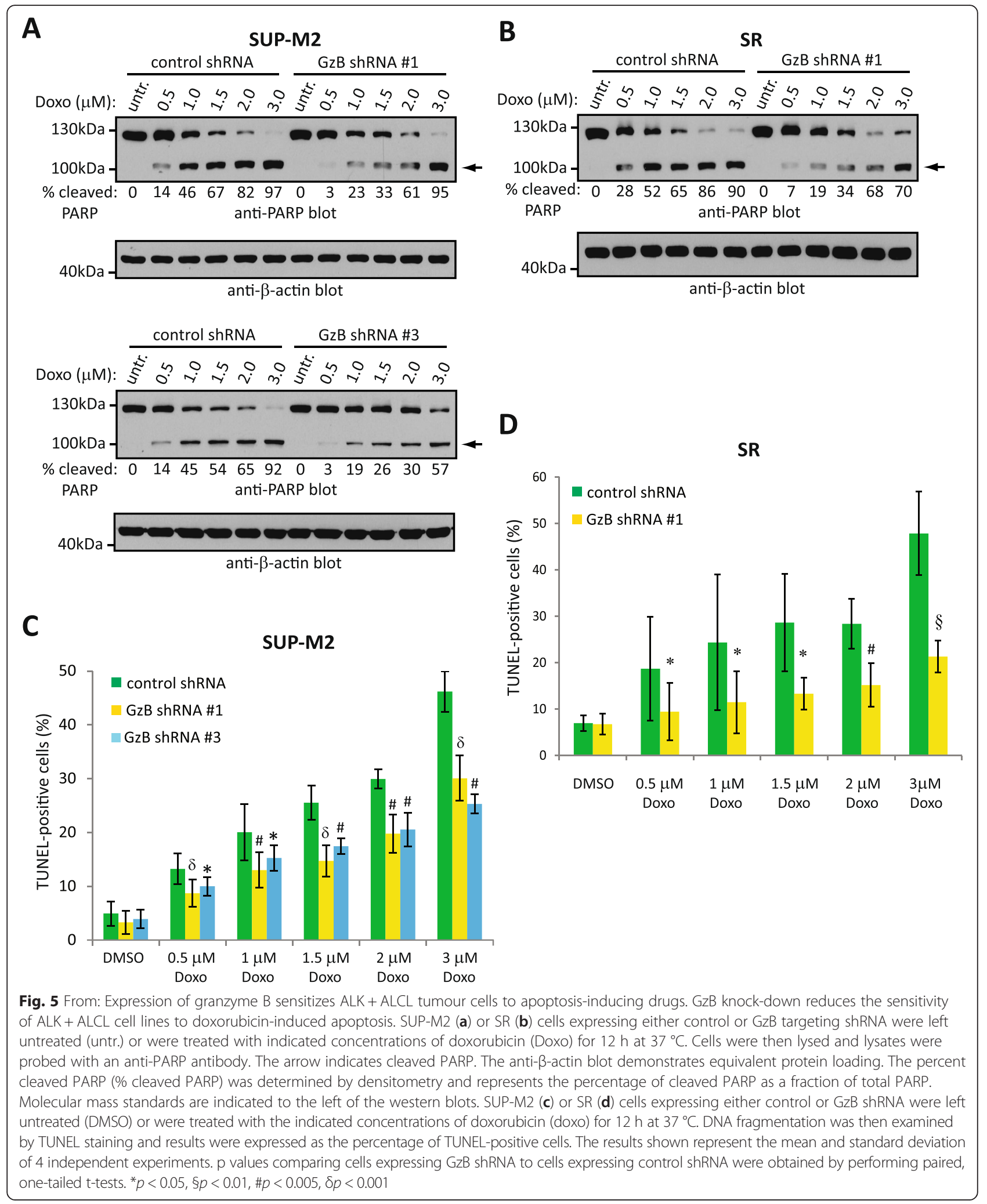

